\title{
Prevalence and Genotypes of GB Virus C/Hepatitis G Virus among Blood Donors in Central Brazil
}

\author{
Luciana A Oliveira, Regina MB Martins $/{ }^{+}$, Megmar AS Carneiro, Sheila A Teles, \\ Simonne A Silva, Divina DP Cardoso, Elisabeth Lampe*, Clara FT Yoshida*
}

Instituto de Patologia Tropical e Saúde Pública, Universidade Federal de Goiás, Caixa Postal 131, 74605-050 Goiânia, GO, Brasil

*Departamento de Virologia, Instituto Oswaldo Cruz-Fiocruz, Rio de Janeiro, RJ, Brasil

A survey was conducted in a blood donor population of Central Brazil aiming to investigate the prevalence of $G B$ virus $C(G B V-C)$ /hepatitis $G$ virus ( $H G V)$ infection and also to analyze the virus genotypes distribution. A total of 241 voluntary blood donors were interviewed at the State Blood Bank in Goiânia, State of Goiás, Brazil. Blood samples were collected and serum samples tested for GBV-C/HGV RNA by polymerase chain reaction. Genotypes were determined by restriction fragment length polymorphism (RFLP) analysis. Seventeen samples were GBV-C/ HGV RNA-positive, resulting in a prevalence of 7.1\% (95\% CI: 4.2-11.1). A significant trend of GBV-C/HGV RNA positivity in relation to age was observed, with the highest prevalence in donors between 29-39 years old. Ten infected individuals were characterized by reporting parenteral (30\%), sexual (18\%), both (6\%) and intrafamiliar (6\%) transmission. However, 7 (40\%) GBV-C/HGV RNA-positive donors did not mention any potential transmission route. RFLP analysis revealed the presence of genotypes 1 and 2 of $G B V-C / H G V$; more precisely, $10(58.9 \%)$ samples were found belonging to the $2 b$ subtype, $4(23.5 \%)$ to the $2 a$ subtype, and $3(17.6 \%)$ to genotype 1 . The present data indicate an intermediate endemicity of $\mathrm{GBV}-\mathrm{C} / \mathrm{HGV}$ infection among this blood donor population, and a predominant circulation of genotype 2 (subtype $2 b$ ) in Central Brazil.

Key words: hepatitis G virus - GB virus C - blood donors - Goiânia - Central Brazil

GB virus $\mathrm{C}(\mathrm{GBV}-\mathrm{C})$ and hepatitis $\mathrm{G}$ virus (HGV) are independent isolates of the same virus which were identified as possible aetiological agent of viral hepatitis in humans (Simons et al. 1995, Linnen et al. 1996). The GBV$\mathrm{C} / \mathrm{HGV}$ can cause persistent infection, but its role in causing liver diseases is still uncertain (Bowden 2001). However, some studies showed that infection with GBV-C/ $\mathrm{HGV}$ can be associated with lower progression of human immunodeficiency virus (HIV) disease in coinfected patients (Lefrère et al. 1999, Yeo et al. 2000, Tillmann et al. 2001, Xiang et al. 2001).

The GBV-C/HGV genome consists of a single-stranded positive sense RNA of approximately $9.4 \mathrm{~kb}$ which has characteristics of a flavivirus-like genome as in the case of the hepatitis C virus (HCV) (Muerhoff et al. 1995), except that unlike $\mathrm{HCV}$, the 5 ' noncoding region (5' NCR) of GBV-C/HGV is variable, and can be used initially to classify natural isolates into three genotypes. Genotype 1 is frequently found in West Africa, genotype 2 predominates in the USA and Europe, and genotype 3 is commonly observed in parts of Asia (Muerhoff et al. 1996, 1997, Mukaide et al. 1997, Okamoto et al. 1997, Katayama et al. 1998). In addition to this classification, 2 novel genotypes were identified. Genotype 4 was described in Myanmar and Vietnam (Naito et al. 2000), and genotype 5

This work received financial support from Conciteg and CNPq. ${ }^{+}$Corresponding author. Fax: +55-62-202.3066. E-mail: rbringel@terra.com.br

Received 7 March 2002

Accepted 12 June 2002 has been found in South Africa (Tucker et al. 1999, Tucker \& Smuts 2000).

GBV-C/HGV is transmitted through blood transfusion and blood components (Schmidt et al. 1996, Roth et al. 1997, Heuft et al. 1998). Epidemiological data suggest that this virus is also spread by sexual and vertical transmission (Bourlet et al. 1999, Stark et al. 1999, Wejstål et al. 1999). However, little is known about other modes of transmission that could explain the high prevalence and worldwide distribution of this virus.

In Brazil, high GBV-C/HGV RNA prevalence rates were found in blood donors from Southeast and Northeast regions (Bassit et al. 1997, Lampe et al. 1998a, Goubau et al. 1999, Pinho et al. 1999). As data concerning GBV-C/HGV infection in other Brazilian regions are still rare, we sought to assess the prevalence of GBV-C/HGV RNA in blood donors in Central Brazil and also to investigate the virus genotypes distribution.

\section{MATERIALS AND METHODS}

Subjects - From June to September 2000, a total of 241 voluntary blood donors accepted for blood donation, after clinical evaluation, at the State Blood Bank in Goiânia, State of Goiás (1,000,000 inhabitants), Central Brazil, were invited to take part of this study, and informed consent was obtained from all participants. The study was approved by the Ethical Committee of the Federal University of Goiás.

A standardized form was used to collect sociodemographic and data as number of previous blood transfusions, acupuncture, tattooing, surgery, intravenous drug use, dental procedure with non-licensed dentist, multiple sex partners, sexually transmitted diseases, and possible household contact with hepatitis. 
Serological tests - Blood samples were collected from all donors and sera were stored at $-20^{\circ} \mathrm{C}$. They were screened for hepatitis B surface antigen ( $\mathrm{HBsAg}$ ), hepatitis B core antibody (anti-HBc) and hepatitis C antibody (anti-HCV) by enzyme-linked immunosorbent assays (ELISA) (Abbott Laboratories, USA). All samples were also tested for alanine aminotransferase (ALT) levels by a colorimetric method (Dolles Laboratory, Brazil).

Detection of $G B V-C / H G V R N A$ - All samples were submitted to RNA extraction, reverse transcription, and a nested polymerase chain reaction (PCR) with primers complementary to the conserved area of the NS5 region of the genome, essentially as described by Lampe et al. (1997).

$G B V-C / H G V$ genotyping - GBV-C/HGV RNA-positive samples were amplified by PCR using primers complementary to the 5' non-coding region (NCR). Genotypes were determined by means of RFLP method (Quarleri et al. 1999). Briefly, amplicons were initially cleaved with Hinf I, and depending on the restriction pattern observed, a second digestion was performed either with Aci I or Aat II. Restriction fragments were resolved in ethidium bromidestained 3\% agarose gels.

Statistical analysis - Prevalence and 95\% confidence intervals (CI) were calculated. Chi-square test, Chi-square for trend test or Fisher's exact test were performed to evaluate the distribution of characteristics associated with GBV$\mathrm{C} / \mathrm{HGV}$ infection. Statistical significance was assessed at the 0.05 probability level in all analyses. Statistical evaluations were performed using Epiinfo 6.0 program developed by the Centers for Disease Control and Prevention (Atlanta, GA).

\section{RESULTS}

The studied population ranged in age from 18 to 60 years (mean $\pm \mathrm{SD}=30.2 \pm 8.5$ years). The majority of the blood donors $(86.7 \%)$ were men. Almost $70 \%$ of them earned less than U\$200 per month and also had less than 8 years of schooling. Forty-eight (19.9\%) were first-time blood donors and 193 (80.1\%) were regular donors. This population consisted of relatives or close friends of hospitalized patients needing blood transfusions.

As shown in Table I, a prevalence of 7.1\% (95\% CI: 4.2-11.1) was found for GBV-C/HGV infection. This donor population showed positivity rates of $5 \%$ and $0.8 \%$ for hepatitis B (anti-HBc) and C (anti-HCV), respectively. All serum samples were negative for $\mathrm{HBsAg}$.

Analysis of the characteristics of this population showed that only age was significantly associated with GBV-C/HGV infection. This infection reached a peak at an age range from 29 to 39 years old; $13.5 \%$ of the blood donors were infected. Moreover, $2.5 \%$ of the age group under 28 years and $6.1 \%$ of age group over 40 years were GBV-C/HGV RNA- positive $\left(\chi^{2}\right.$ for trend $=9.98 ; p=0.018$ ). On the other hand, potential transmission routes associated with parenteral (30\%), sexual (18\%), both $(6 \%)$ and intrafamiliar (6\%) were reported by GBV-C/HGV RNA-positive donors. However, $40 \%$ of them did not mention any known source for infection (Table II). GBV-C/HGV RNApositive individuals ranged in age from 21 to 43 years. All but one were men. The majority of them were regular

\section{TABLE I}

Detection of GB virus C/hepatitis G virus RNA and serological status for hepatitis B and C among 241 blood donors in Central Brazil

\begin{tabular}{lrcc}
\hline Viral markers & \multicolumn{2}{c}{ Positive } & 95\% CI \\
\cline { 2 - 3 } & $\mathrm{n}$ & $(\%)$ & \\
\hline Anti-HBc & 12 & $(5)$ & $2.6-8.5$ \\
Anti-HCV & 2 & $(0.8)$ & $0.1-3.0$ \\
GBV-C/HGV RNA & 17 & $(7.1)$ & $4.2-11.1$ \\
\hline
\end{tabular}

CI: confidence interval

TABLE II

Characteristics of 17 GB virus C/hepatitis G virus RNA-positive blood donors

\begin{tabular}{|c|c|c|c|c|c|c|}
\hline Donor no. & Age (yr) & Gender & Donation & Possible transmission route & Anti-HBc & ALT \\
\hline 1 & 43 & $\mathrm{~F}$ & First & Surgery & - & 15 \\
\hline 2 & 31 & M & Regular & - & - & 10 \\
\hline 3 & 36 & M & Regular & - & - & 17 \\
\hline 4 & 37 & M & Regular & Dental procedure $^{a}$ & - & 26 \\
\hline 5 & 39 & M & Regular & - & + & 28 \\
\hline 6 & 28 & M & Regular & STD & - & 15 \\
\hline 7 & 21 & M & Regular & Multiple partners & - & 14 \\
\hline 8 & 32 & M & Regular & STD & - & 6 \\
\hline 9 & 34 & M & Regular & Multiple partners & - & 17 \\
\hline 10 & 37 & M & Regular & - & - & 23 \\
\hline 11 & 43 & M & Regular & Dental procedure & - & 20 \\
\hline 12 & 29 & M & Regular & Household contact $b$ & - & 26 \\
\hline 13 & 31 & M & First & Transfusion, tattoo, surgery & - & 10 \\
\hline 14 & 25 & M & Regular & Tattoo & + & 28 \\
\hline 15 & 36 & M & Regular & - & - & 8 \\
\hline 16 & 38 & M & Regular & - & - & 23 \\
\hline 17 & 32 & M & Regular & - & - & 21 \\
\hline
\end{tabular}

$a$ : history of dental procedure with non-licensed dentist; $b$ : possible household contact with hepatitis; ALT: alanine aminotransferase; STD: sexually transmitted disease 
blood donors. Two of these donors (nos. 5 and 14) were anti-HBc positive. All GBV-C/HGV infected individuals had normal ALT levels.

All 17 GBV-C/HGV RNA-positive samples were genotyped by RFLP pattern. It was observed that 3 (17.6\%) were of genotype 1 and 14 (82.4\%) of genotype 2 . Of these, 4 isolates belonged to the 2a subtype and 10 to the $2 \mathrm{~b}$ subtype (Figure).
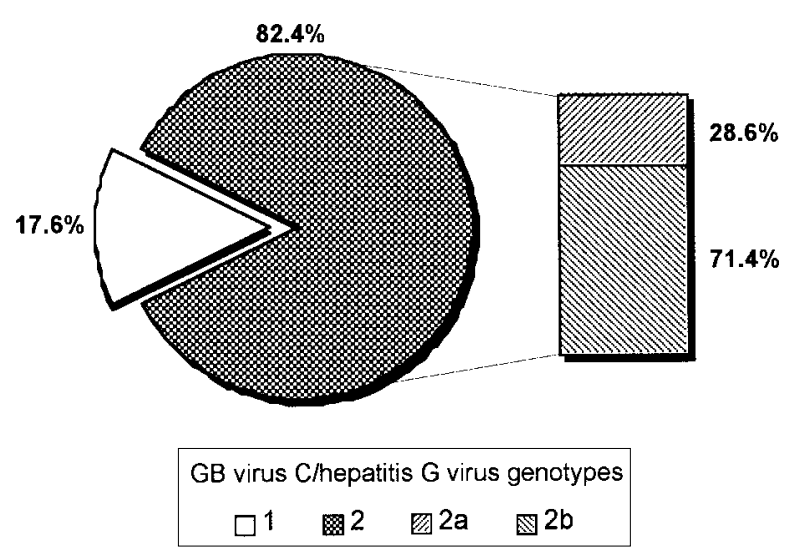

Frequency of GB virus C/hepatitis G virus genotypes in blood donors in Central Brazil.

\section{DISCUSSION}

Epidemiological investigations demonstrated that GBV-C/HGV RNA prevalence among blood donors ranges from $0.5-4 \%$ in the USA, Europe and Japan (Orito et al. 1996, Gutierrez et al. 1997, Nübling et al. 1997, Blair et al. 1998, Mercier et al. 1999, Sauleda et al. 1999) to 10-18.9\% in some African countries (Casteling et al. 1998, El-Zayadi et al. 1999, Sathar et al. 1999). In South America, it has also been reported at a varying range from 5.5\% in Argentina (Oubiña et al. 1999) to $14.6 \%$ in Bolivia (Konomi et al. 1999). In Brazil, rates of $9 \%$ and $10 \%$ were detected in blood donors in São Paulo and Rio de Janeiro (Southeastern region), respectively (Bassit et al. 1997, Lampe et al. 1998a). In addition, $5.2 \%$ and $6.5 \%$ of donors with normal and elevated ALT levels were GBV-C/HGV RNA-positive (Pinho et al. 1999). A prevalence of 8.6\% was found in Fortaleza (Northeastern region) (Goubau et al. 1999). Thus, the prevalence of $7.1 \%$ found in blood donors in Goiânia could be placed in an intermediate position.

The highest prevalence of GBV-C/HGV RNA was seen in the group from 29 to 39 years (13.5\%). A similar finding of age-specific prevalence has been reported by Konomi et al. (1999), with a peak at an age range from 20 to 39 years in healthy Bolivian individuals. In addition, among 170 blood donors in Rio de Janeiro, the seroprevalence of antibody against GBV-C/HGV envelope E2 protein increased with age, from $5.6 \%$ (group with ages between 18 and 24 years) to $35.3 \%$ (donors from 43 to 60 years) (Lampe et al. 1998b). These data may suggest a role for sexual transmission of GBV-C/HGV.
In the present study, prevalence rates of $5 \%$ and $0.8 \%$ were found for hepatitis B and C, respectively. Of the 17 GBV-C/HGV RNA-positive blood donors, two were positive for anti-HBc, but negative for $\mathrm{HBsAg}$, and none of them was coinfected by HCV. In addition, no association was found between GBV-C/HGV RNA status and serum ALT levels. These data indicate that this virus has been independently widespread in healthy individuals in Central Brazil.

We observed the characteristics of the GBV-C/HGV RNA-positive donors. Ten individuals had exposure to one or more factors associated with parenteral $(30 \%)$, sexual (18\%), both (6\%) and intrafamiliar (6\%) transmission. However, it is interesting to note that $40 \%$ of the infected donors did not mention any identifiable source of infection, but they earned less than US\$200 per month and had a low level of education. Thus, low socioeconomic status and poor hygienic conditions occurring in developing countries may contribute to GBV-C/HGV dissemination (Konomi et al. 1999).

To analyze the genetic diversity of GBV-C/HGV isolates among blood donors in Central Brazil, all GBV-C/ HGV RNA-positive samples were genotyped by RFLP. Three samples (17.6\%) belonged to genotype 1 and the remaining $14(82.4 \%)$ to genotype 2 . These data demonstrate the simultaneous circulation of both genotypes, already reported to be predominant in West Africa (genotype 1) and USA/Europe (genotype 2) (Tucker \& Smuts 2000). Recently, the same genotypes were detected in 35 serum samples in a Brazilian rural population (Northeastern region); more precisely, $82.9 \%$ and $17.1 \%$ were characterized as genotypes 2 and 1, respectively (Gallian et al. 1998). Also, Lampe et al. (1998b) showed that 31 isolates from individuals living in Rio de Janeiro (Southeastern region) belonged to three clusters, 2 of which were classified as genotypes 1 and 2 . The presence of both genotypes in Brazil is likely to reflect the European and African origin of the population. In the present study, genetic diversity of genotype 2 revealed that 4 donors were infected with subtype $2 \mathrm{a}$ and 10 with subtype $2 \mathrm{~b}$. In Argentina, genotype 2 was also predominant among blood donors, and subtypes $2 \mathrm{a}$ and $2 \mathrm{~b}$ were equally detected (Oubiña et al. 1999). Genotype 3 was not observed in Brazilian isolates in spite of immigration from Asian countries, but it was found in other populations of South America, such as native Indians from Colombia (Tanaka et al. 1998) and in Bolivians (Konomi et al. 1999).

In conclusion, our data point out an intermediate endemicity of GBV-C/HGV infection in Central Brazil, and that the parenteral route was the presumed means of virus transmission for only one-third of the infected blood donors. This investigation also demonstrates the simultaneous circulation of genotypes 1 and 2, with a high prevalence of subtype $2 b$ of GBV-C/HGV in the study population.

\section{REFERENCES}

Bassit L, Kleter B, Santos GR, Maertens G, Sabino E, Chamone D, Quint W, Sáez-Alquézar A 1997. Hepatitis G virus: prevalence and sequence analysis in blood donors of São Paulo, Brazil. Vox Sang 74: 83-87. 
Blair CS, Davidson F, Lycett C, Mcdonald DM, Haydon GH, Yap PL, Hayes PC, Simmonds P, Gillon J 1998. Prevalence, incidence and clinical characteristics of hepatitis $G$ virus/ $\mathrm{GB}$ virus $\mathrm{C}$ infection in Scottish blood donors. J Infect Dis 178: 1779-1782.

Bourlet T, Guglielminotti C, Evrard M, Berthelot P, Grattard F, Frésard A, Luncht FR, Pozzetto B 1999. Prevalence of GBV-C/hepatitis G virus RNA and E2 antibody among subjects infected with human immunodeficiency virus type 1 after parenteral or sexual exposure. J Med Virol 58: 373377.

Bowden S 2001. New hepatitis viruses: contenders and pretenders. J Gastroenterol Hepatol 16: 124-131.

Casteling A, Song E, Sim J, Blaauw D, Heyns A, Schweizer R, Margolius L, Kuun E, Field S, Schoub B, Vardas E 1998. GB virus $C$ prevalence in blood donors and high risk groups for parenterally transmitted agents from Gauteng, South Africa. J Med Virol 55: 103-108.

El-Zayadi AR, Abe K, Selim O, Naito H, Hess G, Ahdy A 1999. Prevalence of GBV-C/hepatitis G virus viraemia among blood donors, health care personnel, chronic non-B non- $\mathrm{C}$ hepatitis, chronic hepatitis $\mathrm{C}$ and hemodialysis patients in Egypt. $J$ Virol Meth 80: 53-58.

Gallian P, Rodrigues V, Cantaloube JF, Dessein H, Micco P, Dessein AJ, Lamballeri X 1998. High prevalence of GB-C/ hepatitis $\mathrm{G}$ virus in a Brazilian population with helminth infection. J Med Virol 56: 310-315.

Goubau P, Andrade FB, Liu H, Basilio FPS, Croonen L, BarretoGomes VAF 1999. Prevalence of GB virus C/hepatitis G virus among blood donors in north-eastern Brazil. Trop Med Intern Health 4: 365-367.

Gutierrez RA, Dawson GJ, Knigge MF, Melvin SL, Heynen CA, Kyrk CR, Young CE, Carrick RJ, Schlauder GG, Surowy TK, Dille BJ, Coleman PF, Thiele DL, Lentino JR, Pachucki C, Mushahwar IK 1997. Seroprevalence of GB virus C and persistence of RNA and antibody. J Med Virol 53: 167-173.

Heuft HG, Berg T, Schreier E, Künkel U, Tacke M, Schwella N, Hopf U, Salama A, Huhn D 1998. Epidemiological and clinic aspects of hepatitis $\mathrm{G}$ virus infection in blood donors and immunocompromised recipients of HGV-contaminated blood. Vox Sang 74: 161-167.

Katayama K, Kageyama T, Hoshino FB, Fukushi S, Kurihara C, Ishiyama N, Okamura H, Oya A 1998. Full-lengh GBV$\mathrm{C} / \mathrm{HGV}$ genomes from nine Japanese isolates: characterization by comparative analyses. Arch Virol 143: 1063-1075.

Konomi N, Miyoshi C, Zerain CF, Li T, Arakawa Y, Abe K 1999. Epidemiology of hepatitis B, C, E and G virus infection and molecular analysis of hepatitis $\mathrm{G}$ isolates in Bolivia. J Clin Microbiol 37: 3291-3295.

Lampe E, Oliveira JM, Pereira JL, Saback FL, Yoshida CFT, Niel C 1998a. Hepatitis G virus (GBV-C) infection among Brazilian patients with chronic liver disease and blood donors. Clin Diag Virol 9: 1-7.

Lampe E, Saback FL, Viazov S, Roggendorf M, Niel C 1998b. Age-specific prevalence and genetic diversity of GBV-C/ hepatitis G virus in Brazil. J Med Virol 56: 39-43.

Lampe E, Saback FL, Yoshida CFT, Niel C 1997. Infection with GB virus $\mathrm{C} /$ hepatitis $\mathrm{G}$ virus in Brazilian hemodialysis and hepatitis patients and asymptomatic individuals. J Med Virol 52: 61-67.

Lefrère JJ, Férec C, Roudot-Thoraval F, Loiseau P, Cantaloube JF, Biagini P, Mariotti M, LeGac G, Mercier B 1999. GBV$\mathrm{C} /$ hepatitis $\mathrm{G}$ virus (HGV) RNA load in immunodeficient individuals and in immunocompetent individuals. $\mathrm{J} \mathrm{Med}$ Virol 59: 32-37.

Linnen J, Wages J, Zhang-Zeck ZY, Fry KE, Krawczynski KZ, Alter H, Koonin E, Gallagher M, Alter M, Hadziyannis S,
Karayiannis P, Fung K, Nakatsuji Y, Shih JWK, Young L, Piatak Jr M, Hoover C, Fernandez J, Chen S, Zou JC, Morris T, Hyams KC, Ismay S, Lifson JD, Hess G, Foung SKH, Thomas H, Bradley D, Margolis H, Kim JP 1996. Molecular cloning and disease association of hepatitis G virus: a transfusion transmissible agent. Science 271: 505508.

Mercier B, Barclais A, Botte C, Cantaloube JF, Coste J, Defer C, Gautreau C, Giannoli C, Halfon P, Lepot I, Loiseau P, Martial J, Montcharmont P, Merel P, Ouzan D, Ravera N, Follana J, Césarie R, Janot C, Lemarie JM, De Micco JM, Venoz G, Férec C 1999. Prevalence of GBV-C/HGV RNA and GBV-C/HGV antibodies in French volunteer blood donors: results of a collaborative study. Vox Sang 76:166169.

Muerhoff AS, Leary TP, Simons JN, Pilot-Matias TJ, Dawson GJ, Erker JC, Chalmers ML, Schlauder ML, Desai SM, Mushahwar IK 1995. Genomic organization of GB viruses A and B: two new members of the Flaviviridae associated with GB agent hepatitis. J Virol 69: 5621-5630.

Muerhoff AS, Simons JN, Leary TP, Erker JC, Chalmers ML, Pilot-Matias TJ, Dawson GJ, Desai SM, Mushahawar IK 1996. Sequence heterogeneity within the 5'-terminal region of the hepatitis GB virus $\mathrm{C}$ genome and evidence for genotypes. J Hepatol 25: 379-384.

Muerhoff AS, Smith DB, Leary TP, Erker JC, Desai SM, Mushahwar IK 1997. Identification of GB virus C variants by phylogenetic analysis of 5'-untranslated and coding region sequences. $J$ Virol 71: 6501-6508.

Mukaide M, Mizokami M, Orito E, Ohba K, Nakano T, Ueda R, Hikiji K, Iino S, Shapiro S, Lahat N, Park YM, Kim BS, Oyunsuren T, Rezieg M, Al-Ahdal MN, Lau JYN 1997. Three different GB virus C/hepatitis $\mathrm{G}$ virus genotypes. Phylogenetic analysis and a genotyping assay based on restriction fragment length polymorphism. FEBS Lett 407: 51-58.

Naito H, Hayashi S, Abe K 2000. The entire nucleotide sequence of two hepatitis $\mathrm{G}$ virus isoltes belonging to a novel genotype: isolation in Myanmar and Vietnam. J Gen Virol 81: 189-194.

Nübling CM, Bialleck H, Fürsch AJ, Scharrer I, Schramm W, Seifried E, Schmidt U, Staszewski S, Lower J 1997. Frequencies of $\mathrm{GB}$ virus $\mathrm{C}$ / hepatitis $\mathrm{G}$ virus genomes and of specific antibodies in German risk and non-risk populations. J Med Virol 53: 218-224.

Okamoto H, Nakano H, Inoue T, Fukuda M, Kishimoto J, Ilizuda H, Tsuda F, Miyakawa Y, Mishiro M 1997. The entire nucleotide sequence of two GB virus C/hepatitis G virus isolates of distinct genotypes from Japan. J Gen Virol 78: 737-745.

Orito E, Mizokami M, Nakano T, Wu R, Cao K, Ohba K, Ueda R, Mukaide M, Hikiji K, Matsumoto Y, Iino S 1996. GB virus $\mathrm{C} /$ hepatitis $\mathrm{G}$ virus infection among Japanese patients with chronic liver diseases and blood donors. Virus Res 46: 89-93.

Oubiña JR, Mathet V, Feld M, Della Lata MP, Ferrario D, Verdun R, Libonatti O, Fernández J, Carballal G, Sánchez DO, Quarleri JF 1999. Genetic diversity of GBV-C/HGV strains among HIV infected-IVDU and blood donors from Buenos Aires, Argentina. Virus Res 65: 121-129.

Pinho JRR, Zanotto PMA, Ferreira JLP, Sumita LM, Carrilho FJ, Silva LC, Capacci ML, Silva AO, Guz B, Gonçales Jr FL, Gonçales NSL, Buck GA, Meyers GA, Bernardini AP 1999. High prevalence of GB virus C in Brazil and molecular evidence for intrafamiliar transmission. J Clin Microbiol 37: 1634-1637.

Quarleri JF, Mathet VL, Feld M, Ferrario D, Della Lata MP, 
Verdun R, Sánchez DO, Oubinã JR 1999. GB virus C/hepatitis $\mathrm{G}$ virus groups and subgroups: classification by a restriction fragment length polymorphism method based on phylogenetic analysis of the 5' untranslated region. J Clin Microbiol 37: 1340-1347.

Roth WK, Waschk D, Marx S, Tschauder S, Zeuzem S, Bialleck H, Weber H, Seifried E 1997. Prevalence of hepatitis G virus and its strain variant, the GB agent, in blood donations and their transmission to recipients. Transfusion 37: 651-655.

Sathar MA, Soni PN, Naicker S, Conradie J, Lockhat F, Gouws E 1999. GB virus C/hepatitis G virus infection in KwaZulu Natal, South Africa. J Med Virol 59: 38-44.

Sauleda S, Esteban JI, Hernandez JM, Reesink H, Castella D, Quer J, Hess G, Esteban R, Guardia J 1999. Evaluation of RNA and E2 antibodies in prospectively followed recipients of hepatitis G virus-infected blood. Transfusion 39: 633-688.

Schmidt M, Korn K, Fleckenstein B 1996. Molecular evidence for transmission of hepatitis $\mathrm{G}$ virus by blood transfusion. Lancet 347: 909.

Simons JN, Leary TP, Dawson GJ, Pilot-Matias TJ, Muerhoff AS, Schlauder GG, Desai SM, Mushahwar IK 1995. Isolation of a novel virus-like sequence associated with human hepatitis. Nature Med 1: 564-569.

Stark K, Doering CD, Bienzele U, Pauli G, Hamouda O, Engel AM, Schreier E 1999. Risk and clearence of GB virus C/ hepatitis $\mathrm{G}$ virus infection in homosexual men: a longitudinal study. J Med Virol 59: 303-306.
Tanaka Y, Mizokami M, Orito E, Ohba K, Nakano T, Kato T, Kondo Y, Ding X, Ueda R, Sonoda S, Tajima K, Miura T, Hayami M 1998. GB virus C/hepatitis G virus infection among Colombian native Indians. Am J Trop Med Hyg 59: 462-467.

Tillmann HL, Heiken H, Botor-Knapik A, Heringlake S, Ockenga J, Wilber JC, Goergen B, Detmer J, McMorrow M, Stoll M, Schmidt RE, Manns MP 2001. Infection with GB virus $\mathrm{C}$ and reduced mortality among HIV-infected patients. N Engl J Med 345: 715-724.

Tucker TJ, Smuts HE 2000. GBV-C/HGV genotypes: proposed nomeclature for genotypes 1-5. J Med Virol 62: 8283.

Tucker TJ, Smuts HE, Eickhaus P, Robson SC, Kirsch RE 1999. Molecular characterization of the 5' non-coding region of South African GBV-C/HGV isolates: major deletion and evidence for a fourth genotype. J Med Virol 59: 52-59.

Wejstål R, Månson A, Widell A, Norkrans G 1999. Perinatal transmission of hepatitis $G$ virus (GB virus type $C$ ) and hepatitis $\mathrm{C}$ virus infections - a comparison. Clin Infect Dis 28: 816-821.

Xiang J, Wunschmann S, Dikema DJ, Klinzaman D, Patrick KD, George SL, Stapleton JT 2001. Effect of coinfection with GB virus $\mathrm{C}$ on survival among patients with HIV infection. N Engl J Med 345: 707-714.

Yeo AET, Matsumoto A, Hisada M, Shih JM, Alter HJ, Goedert JJ 2000. Effect of hepatitis G virus infection on progression of HIV infection in patients with hemophilia. Ann Intern Med 132: 959-963. 
958 GBV-C/HGV in Blood Donors - Luciana A Oliveira et al. 